role of regional context. Technovation (2018), https://doi.org/10.1016/j.technovation.2018.06.007.

10. Rozentale, I., Lavanga, M. (2014). The "universal" characteristics of creative industries revisited: The case of Riga. City, Culture and Society, 5 (2014), 55-64.

11. Townsend, L., Wallace, C., Fairhurst, G., Anderson, A. (2017). Broadband and the creative industries in rural Scotland. Journal of Rural Studies, 54 (2017), 451-458.

12. European agenda for Culture Work Plan for Culture 2015-2018 - open method of coordination (OMC) Working Group of EU Member States experts on access to finance for the cultural and creative sectors. November 2015.

13. Green Paper, unlocking the potential of cultural and creative industries. European Commission. 2010.

14. Innovation Strategy for smart specialization of the Republic of Bulgaria (2014-202)

15. National Development Programme: Bulgaria 2020.

16. Regulation (EU) No 1287/2013 of the European Parliament and of the Council of 11 December 2013 establishing a Programme for the Competitiveness of Enterprises and small and medium-sized enterprises (COSME) (2014 - 2020) and repealing Decision No 1639/2006/EC

17. Regulation (EU) no 1295/2013 of the European Parliament and of the Council of 11 December 2013 establishing the Creative Europe Programme (2014 to 2020) and repealing Decisions No 1718/2006/EC, No 1855/2006/EC and No 1041/2009/EC.

18. Strategy 2020 - A European strategy for smart, sustainable and inclusive growth URL: http://2020.eufunds.bg

УДК 330.342.2(100)

JEL classification: L16, E32, F02

Войтко С. В.

доктор економ. наук, професор, ORCID ID: 0000-0002-2488-3210

Національний технічний університет Украйни «Київський політехнічний інститут імені Ігоря Сікорського»

\title{
РОЗВИТОК ЕКОНОМІК КРАЇН В УМОВАХ NEXT NORMALITY TA INDUSTRY 4.0
}

\section{DEVELOPMENT OF COUNTRIES IN CONDITIONS OF THE NEXT NORMALITY AND INDUSTRY 4.0}

Обтрунтовано актуальність дослідження можливості та необхідності розвитку економік світу на засадах Next Normality ma Industry 4.0. Виявлені деякі з причин прояву нового глобального економічного кризового явища на порозі третього десятиліття XXI століття та привід до иієєї кризи у якості SARS-CoV-2. Простежено тенденції зміни показників «Сфера послуг, додана вартість на одного працівника (дол. США за иінами 2010 року)» та «Промисловість (включаючи будівництво), додана вартість на одного прачівника (дол. США за цінами 2010 року)» в Україні та на глобальному рівні (приведено до усіх краӥн, а дослідження здійснено за даними за період з 1991 по 2019 рік). Доведено, щуо у явному вигляді иі показники є інформативними для економічної сфери з позииії кризових трансформацій у суспільстві: 1991р.; 1997p.; 2008p.; 2018p. (реальний 
прояв кризи у 2020 рочі). Виявлено, щу Україна з 2015 року активно розвиває, на противагу світовій тендениії, сферу послуг і промисловість, а ие є можливістю посідання гідного місия в постCOVID 'ній глобальній економіці. Досліджено зміни значення індикаторів з праџі The Worldwide Governance Indicators: "Political Stability and Absence of Violence/Terrorism» ma "Government Effectiveness» 3 a доступний період. Надано рекомендації стосовно розвитку національної економіки України на засадах Iндустрії 4.0 в умовах Next Normality з врахуванням розвитку інформаційно-комунікаиійних технологій та політичної стабільності. Наведені основні виклики для України, складності для інтенсивного розвитку країни, перспективні інвестиційні ніші. Зосереджено увагу на решорингу як конщепиї розмімення в краӥні виробництв європейських підприємств, які певний час назад були перенесені до інших країн з більш дешевою робочою силою. Окреслено наявність в Україні інституиій розбудови начіональної економіки на принципах нової реальності в умовах Індустрії 4.0. Наголошено про те, щэо Індустрія $4.0 \epsilon$ новою об' 'ктивною реальністю у розвитку економік країн в умовах Next Normality.

Ключові слова: Індустрія 4.0, Next Normality, сфера послуг, промисловість, політична стабільність.

The article substantiates the relevance of investigating the possibility and necessity of development of global economies based on Next Normality and Industry 4.0. Some of the causes of the new global economic crisis on the threshold of the third decade of the XXI century and the reason for this crisis as SARS-CoV-2 have been identified. The trends of changes in the indicators "Services, the added value per employee (US dollars at 2010 prices)" and "Industry (including construction), the added value per employee (US dollars at 2010 prices)" in Ukraine and in a global level (brought to all countries, and the study was conducted according to data for the period from 1991 to 2019). It is proved that these indicators are explicitly informative for the economic sphere from the standpoint of crisis transformations in society: 1991; 1997; 2008; 2018 (a real manifestation of the crisis in 2020). It was found that since 2015, Ukraine has been actively developing, in contrast to the global trend, the service sector and industry, and this is an opportunity to take a worthy place in the post-COVID global economy. The changes in the value of The Worldwide Governance Indicators: "Political Stability and Absence of Violence / Terrorism" and "Government Effectiveness" over the available period have been studied. Recommendations for the development of the national economy of Ukraine based on Industry 4.0 in the context of Next Normality, considering the development of information and communication technologies and political stability. The main challenges for Ukraine, difficulties for intensive development of the country, perspective investment niches have resulted. The focus is on reshoring as a concept of locating in the country the production of European enterprises, which some time ago were transferred to other countries with cheaper labor. The existence of institutions of national economic development in Ukraine on the principles of the new reality in the conditions of Industry 4.0 is outlined. It is emphasized that Industry 4.0 is a new objective reality in the development of economies in the context of Next Normality

Keywords: Industry 4.0, Next Normality, services, industry, political stability.

Вступ. Значна кількість країн на порозі третього десятиліття XXI століття у 2020 році перебуває у передкризовому або вже у кризовому стані. Приводом до цього слугував COVID 19, а причин є декілька і ці причини були відомі ще декілька років тому. Пізніше про них. Так, 
наслідком актуалізації причин є стан соціально-економічних систем переважної більшості країн. Цивілізація не стоїть на місці і в умовах, де «виживає сильніший», необхідно вже приймати зважені державницькі рішення на рівні країн та інтеграційних угрупувань про зміну парадигми розвитку суспільства. Стосовно розвитку України, то автор вбачає основними базисами цього розвитку використання засад Індустрії 4.0 (англ. Industry 4.0) в умовах «нової нормальності» (англ. Next Normality, хоча дослівний переклад - «наступна реальність», проте, як i у випадку «Next Generation» перекладається у багатьох публікаціях як «нове покоління»).

В Україні 25-29 травня 2020 р. відбувся Форум, на якому були обговорені проблемні питання Next Normality в Україні [1]. Автор статті брав активну участь у роботі цьому форумі. Саме виступи доповідачів, обговорення учасників, прийняті рішення і пропозиції форуму певним чином наштовхнули на підготовку цієї статті. Ще до цього автором опрацьовано значний обсяг відкритої інформації 3 Індустріі 4.0.

Проблематика розвитку вітчизняного сегменту Індустрії 4.0 значною мірою висвітлюється на українському ресурсі [2]. Належним чином у світовому співтоваристві проблематика Індустрії 4.0 представлена на платформі [3]. Систематизацію матеріалів з Індустрії 4.0 здійснили М. Герман (M. Hermann), Т. Пентек (T. Pentek), Б. Отто (B. Otto) у науковій праці [4]. Започаткував на міжнародному рівні підтримку засад Індустрії 4.0 Клаус Шваб (голова Всесвітнього економічного форуму). Він у статті «The Fourth industrial revolution: what it means and how to respond» [5] описав переваги масової діджиталізації (англ. Digitalization): 1) експоненціальне зростання інновацій (це стосується як швидкості реалізації, так і їх кількості, а також їхнього впливу, що безпосередньо визначає ефективність, продуктивність і скорочення обсягів витрат); 2) зростання обсягу доступних даних і можливостей їх використання для генерації нових знань, об'єднуючи інтелектуальні здібності розробників і користувачів; 3) розвиток штучного інтелекту (розроблення апаратного та програмного забезпечення, а також сенсорів). В Україні питаннями промислової політики займалися С. Ангел і В. Кравчук [6], загрози та можливості розглянув П. Калита [7], І. Новак і Р. Покотиленко дослідили зайнятість в Індустрії 4.0 [8]. Значна кількість робіт свідчить про актуальність проблематики.

Постановка завдання. Цілі дослідження: 1) довести актуальність розвитку економік світу на засадах Next Normality та Industry 4.0; 2) виявити передумови та привід до нової глобальної економічної кризи; 3) простежити тенденції зміни показників «Сфера послуг, додана вартість на одного працівника (дол. США за цінами 2010 року)» та 
«Промисловість (включаючи будівництво), додана вартість на одного працівника (дол. США за цінами 2010 року)» в Україні та на глобальному рівні; 4) дослідити зміну індикаторів «Political Stability and Absence of Violence/Terrorism» та «Government Effectiveness» за доступний період; 5) надати рекомендації стосовно розвитку національної економіки України на засадах Індустрії 4.0 в умовах Next Normality.

Методологія. Концептуальні засади дослідження базуються на положеннях Next Normality, Industry 4.0, на праці «The Worldwide Governance Indicators» [11]. Візуалізація динаміки здійснена на основі використання офіційних даних The World Bank Group [11] i Worldwide Governance [11]. Висновки надані 3 використанням положень системного аналізу.

Результати дослідження. Україна $\epsilon$ європейською країною 3 давньою історією. Нащадки народу засновників Київської Русі розвивали й розвивають освіту та науку. Ось декілька фактів про напрацьований віками освітній потенціал України.

Перша школа в Україні була створена у Львові у 1586 році й носила назву «Львівська братська школа» [9, с. 340]. Згодом такі школи були організовані в багатьох інших містах на території України. Стосовно розвитку вищої освіти, то перший такий заклад в Україні був заснований у 1576 році - Острозька Академія (Рівненська область). Інші провідні заклади вищої освіти також мають тривалу історію: Києво-Могилянська Академія - заснована у 1615 р.; Львівський національний університет імені Івана Франка - 1661 р.; Харківський національний університет імені В. Н. Каразіна - 1804 р.; Національний університет «Львівська політехніка» - 1816 р.; Київський університет імені Тараса Шевченка - 1834 р.; Національний технічний університет України «Київський політехнічний інститут імені Ігоря Сікорського»1898 р. До того ж слід зазначити, що підручник «Граматика» Мелетія Смотрицького (повна назва «Грамматіки Славенскиа правилноє Сvнтагма») вийшов у 1619 році [10].

Розвиток системи освіти безпосередньо пов'язаний з розвитком соціально-економічної системи країни. SMART-країни мають як потужну економіку, так і розвинене освітнє середовище. На сьогодні, на 2020 рік стан глобальної економіки визначився як протидія SARS$\mathrm{CoV}-2$ і призвів до необхідності перегляду соціально-економічних відносин, у тому числі й в Україні. Трансформаційні процеси в економічних системах зумовили появу такого поняття як Next Normality. Загалом, ця нормальність $\epsilon$ продуктом закономірного розвитку міжнародних відносин за формулою «інтернаціоналізація інтеграція - глобалізація» впродовж останніх 70 років. Глобальний 
виклик SARS-CoV-2 зобов'язав стейкхолдерів переглядати економічні відносини у системі «виробник-споживач».

Ці відносини опосередковано визначаються тією доданою вартістю, яка створюється промисловістю та сферою послуг. Цей показник $\epsilon$ інформативним для економічної сфери 3 позиції кризових трансформацій у суспільстві. 3 джерела [11] обрано значення доданої вартості сфери послуг i промисловості. 3 метою забезпечення співрозмірності даних на тривалому проміжку часу спостереження (1991-2019pр.), за який суттєво змінилися як чисельність населення, так і ціни, взято за основу додану вартість за цінами 2010 року та приведено цю вартість на одного працівника. Такий підхід надає можливість зменшити розбіжності в оцінюванні значень на досить тривалому часовому відтинку. Траєкторія зміни співвідношення показників «Сфера послуг, додана вартість на одного працівника (дол. США за цінами 2010 року)» та «Промисловість (включаючи будівництво), додана вартість на одного працівника (дол. США за цінами 2010 року)» наведена на рис. 1.

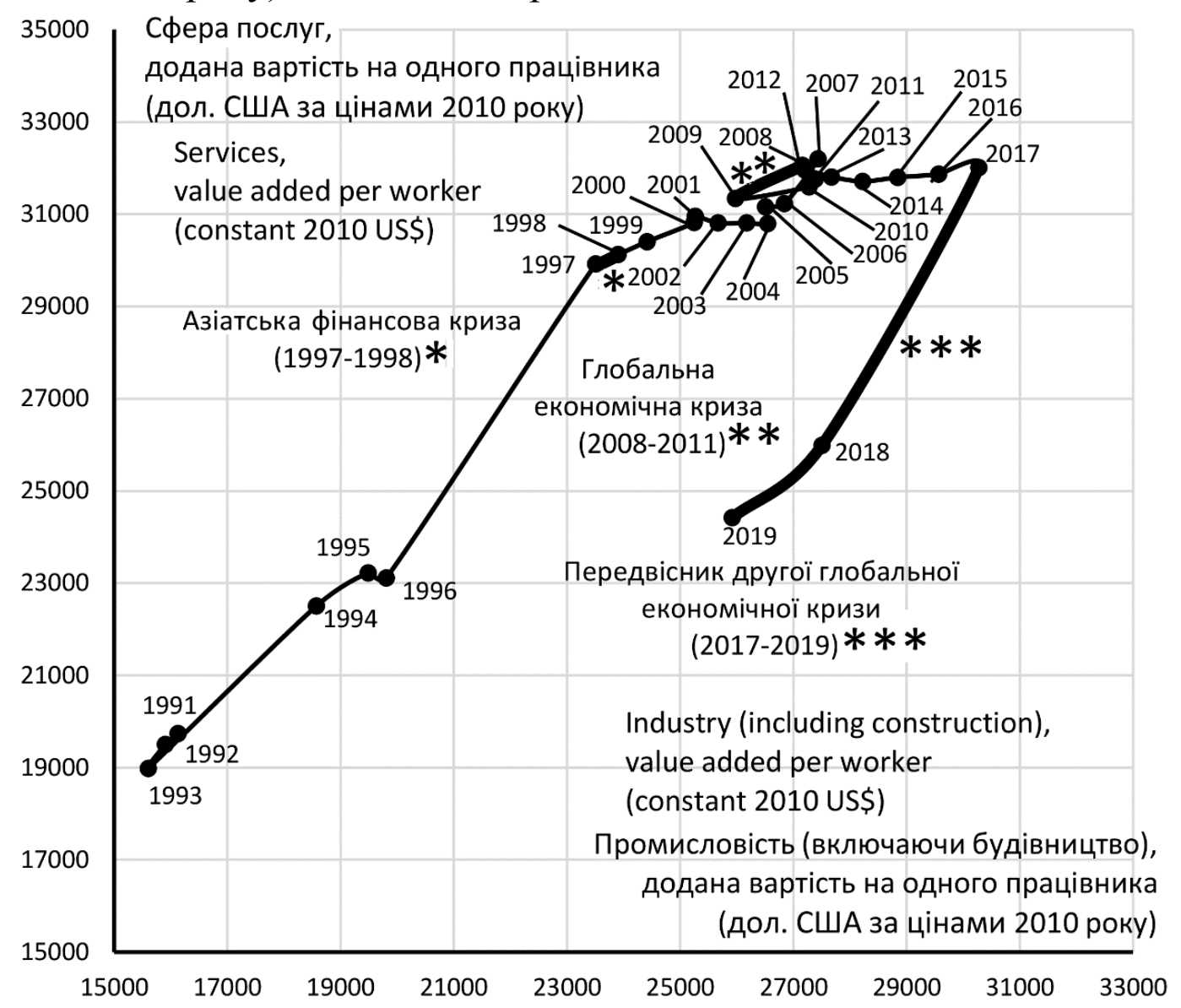

Рисунок 1 - Траєкторія зміни співвідношення доданої вартості для сфери послуг і промисловості, приведених на одного працівника у доларах США за цінами 2010 року у світі 
Виділяється декілька характерних відтинків часу. Крах у 1991 році соціалістичного табору, який довів свою неспроможність у еволюційному розвитку, призвів до незначного зниження активності як у промисловості, так і у сфері послуг у світі загалом. Суттєве зростання цих двох сфер діяльності відбувалося до 1997 року, до початку азійської фінансової кризи (позначено однією «*»). Ця криза призупинила зростання доданої вартості у промисловості та сфери послуг. Ця «зупинка» зумовила незначні темпи зростання ще до 2007 року. Глобальна економічна криза 2008-2011pp. (період позначено «**») суттєво зменшила додану вартість для промисловості та незначно для сфері послуг. Надалі, знову 10 років поспіль спостерігалося незначне зростання значень обох показників. Надто суттєвих змін ці показники отримали у 2018 та 2019 роках. Маємо суттєве зменшення навіть до рівня 1995-1996рр. Зазначене можна рахувати як передвісник нової глобальної економічної кризи (період позначено «***», яка насправді відбулася і стала відчутною на початку 2020 року.

На рис. 2 візуалізовано фазовий портрет цих же показників для України.

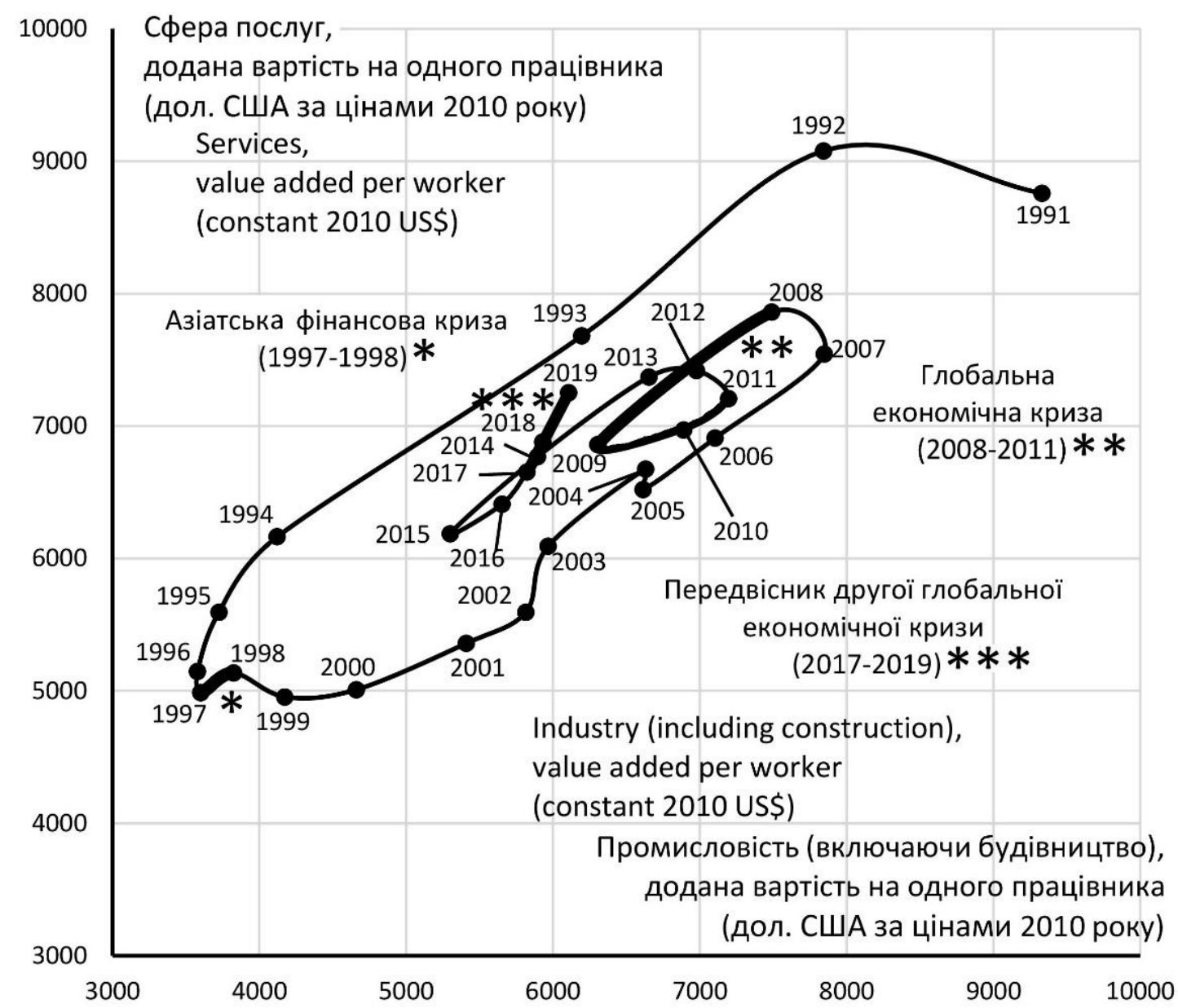


Рисунок 2 - Траєкторія зміни співвідношення доданої вартості для сфери послуг і промисловості, приведених на одного працівника у доларах США за цінами 2010 року для України

Варто зазначити, що Україна в 1991-1992 роках мала значний потенціал для розвитку, адже у ці роки були максимальні значення доданої вартості для промисловості та сфери послуг. Отримання країною незалежності, перехід від планової до ринкової економіки та інші фактори знизили значення цих показників. Азіатська фінансова криза практично не вплинула на значення доданої вартості в Україні, хоча привела до девальвації національної валюти. А от глобальна економічна криза (2008-2011pp.) суттєво знизила ці значення. Варто наголосити про те, що натепер, починаючи 32015 року, Україна активно розвиває сферу послуг і промисловість, про що свідчить стале зростання обсягів доданої вартості. Національна економіка має використати цей факт у посіданні гідного місця в постCOVID`ній глобальній економіці третього десятиліття XXI століття.

3 метою визначення можливості прориву в розвитку України проаналізуємо політичну стабільність (Political Stability and Absence of Violence/Terrorism) i ефективність роботи уряду (Government Effectiveness) за період з 1996 року по 2018 рік (доступні дані на середину 2020 року). На рис. 3 наведено фазовий портрет цих показників [12].

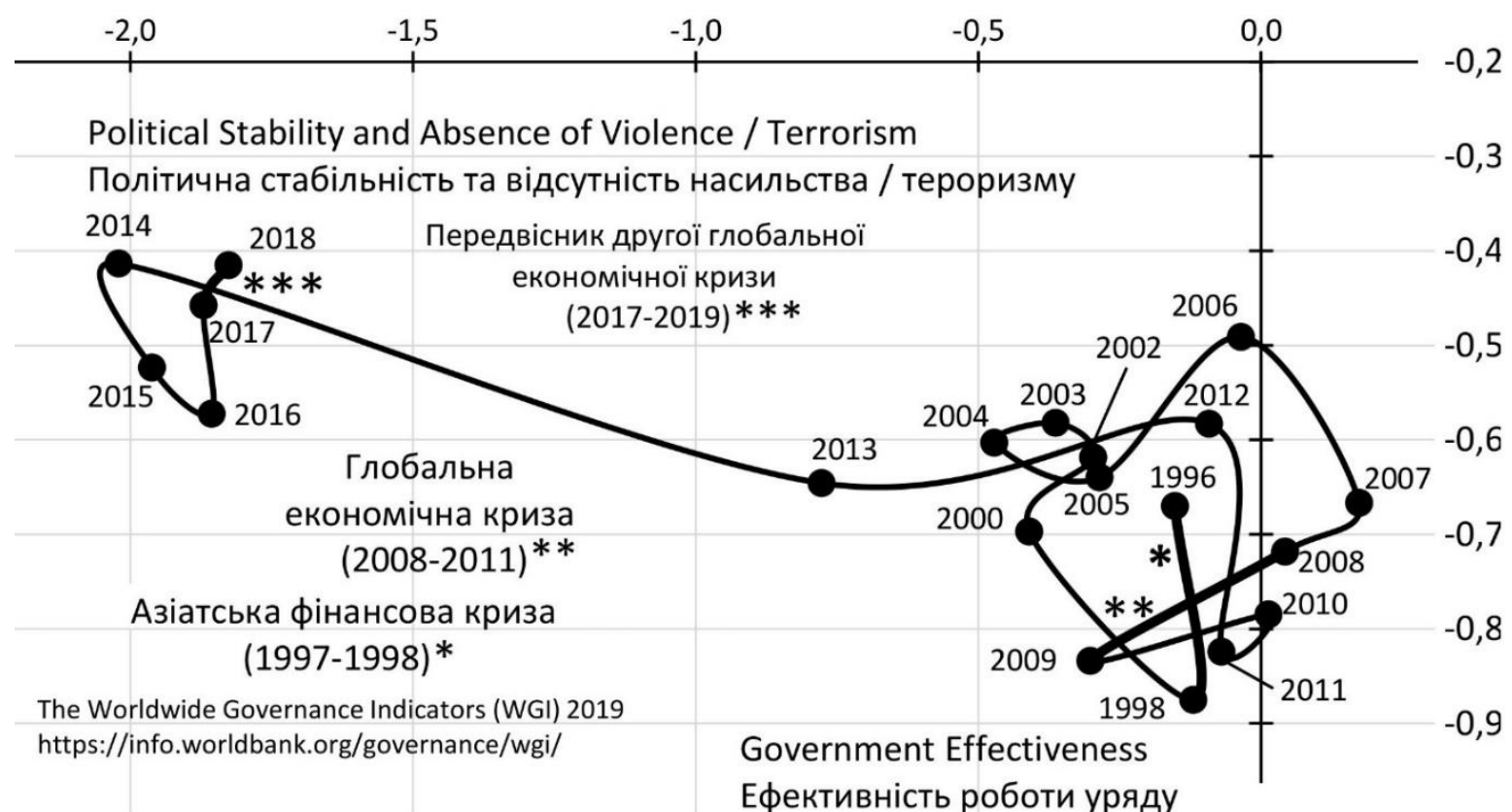

Рисунок 3 - Фазовий портрет зміни показників «Політична стабільність та відсутність насильства / тероризму» та «Ефективність роботи уряду» за період 1996-2018pp. 
До 2012 року значення показника «Ефективність роботи уряду» нижче середнього аніж у світі, а політична стабільність незначно менша чи близька до середнього у світі. А от вже з 2013 року розпочалися суттєві трансформаційні процеси в соціально-економічній, політичній сферах України. Про це також свідчить цей графік. Варто звернути увагу, що вже з 2016 року спостерігається позитивна тенденція у зміні цих показників на краще. Це можна використати саме для стабілізації та розвитку національної економіки при відповідних управлінських рішеннях на вищому державному рівні.

Зважаючи на зростання обсягів доданої вартості в індустрії та сфері послуг, зважаючи на незначні, але ж певні позитивні тенденції у розбудові держави, тобто при наявності цих передумов можливим $\epsilon$ прорив у розвитку національної економіки. За цими цифрами ми готові, а чи готове суспільство? До чого готуватися нам у новій реальності (Next Normality)?

Прослідкуємо розвиток сучасної цивілізації у частині економіки. Розвиток завжди зумовлювався обміном (торгівлею), який здійснювався певними носіями (жива сила, механізми) об'єктів обміну (товари та послуги). Обмінювалися товарами, які спочатку носили пішки, потім перевозили домашніми тваринами (коні, верблюди тощо). Тисячоліттями міжконтинентальні перевезення здійснювалися суднами морем. Тільки декілька століть тому товари переміщали на паровозах, дещо більше століття у цей процес долучилися автомобілі, відносно недавно літаки. I зовсім недавно - космічними ракетами доставляли супутники на орбіту. Інформаційно-комунікаційні технології близько півстоліття тому (мережа інтернет) надали можливість обмін здійснювати інформацією на принципово новому рівні. Так, у будьякому випадку інформацією обмінювалися завжди при обміні товарами - передавалися знання 3 території на іншу територію. А от обмін інформацією принципово змінився з появою сайтів (1990 рік). Ці 30 років - незначний відтинок часу у розвитку цивілізації, проте виявився вирішальним у глобальній кризі 2020 року.

Поява автомобілів зумовила створення дорожньої інфраструктури та автосервісу, поява авіасполучень підштовхнула цивілізацію до розвитку аеропортової інфраструктури. Відповідно, мережа інтернет і зростаюча потреба в інформації надала людству інформаційнокомунікаційну інфраструктуру. Самоізоляція на карантині та дистанційна робота об'єктивно знизила потребу у пересуванні та у деяких товарах і послугах. Проте зросли потреби у інформаційнокомунікаційних послугах. Світ вже не буде колишнім. До чого ж готуватися?

Основними викликами для України на сьогодні $\epsilon$ такі: 1) продовження експлуатації морально застарілих, технологічно 
відсталих ідей; 2) наявний дисбаланс суспільного запиту на IT’ішніків, інженерів i фахівців гуманітарного спрямування. До цього можна додати й інші. Складністю для інтенсивного розвитку країни є пошук конкурентоспроможних інвестиційно привабливих проектів для нової реальності. Перспективними інвестиційними нішами можуть бути технології забезпечення соціального дистанціювання, віддаленого керування, моніторингу та контролю технологічних процесів i середовища життєдіяльності Людини. Зазначене потребує такого: 1) зміни парадигми, перегляд пріоритетів і традиційних поглядів на соціально-економічну систему нової реальності; 2) адаптація суспільства до нової інфраструктурної реальності у промисловості, сфері послуг, аграрному секторі, енергетиці; 3) діджиталізація як об'єктивна реальність і потреба при проектуванні та експлуатації технологічного обладнання.

Одним 3 основних напрямів трансформації промисловості на сьогодні є решоринг. Решоринг може бути концепцією повернення до країни виробництв, які певний час назад були перенесені до інших країн 3 більш дешевою робочою силою. Таке «повернення» підприємств додає кількості робочих місць у країні-базування, чим покращує соціально-економічний стан, якість і безпеку життя Людини у цій країні. $Є С$ вже має готовність для решорингу та розробляє програми відновлення економіки Свропейського Союзу. В Україні за відомих причин мова про класичний решоринг не йде. Мова може йти лише про переміщення виробництв європейських компаній з азійських країн до України, що вигідно для Європи саме географічним положенням і відносно дешевою та досить кваліфікованою робочою силою.

3 цією метою основна увага влади має концентруватися на трансформаціях у сфері технологій, на переформатуванні екосистем, на формуванні кластерів, на експортоорієнтованої промисловості за умови сприйняття глобалізаційних викликів. Глобалізація натепер привела до періоду «великої взаємної ізоляції», що порушило глобальні ланцюжки постачання, тому решоринг став ще й механізмом національного протекціонізму. Ланцюжки постачання трансформуватимуться й надалі саме за категоріями постачань і переробки сировини. Формуватися будуть новітні ланцюжки постачання знань, умінь, навичок, компетенцій, ідей. Проте, натепер спостерігається основний розрив в екосистемі між науковцями та університетами, з одного боку, та промисловими підприємствами, 3 іншого. Асоціацією підприємств промислової автоматизації України розроблено Ландшафт українських інноваторів Індустрії 4.0 - «Аналітичний огляд інноваторів і стану інновацій в Україні «Landscape Industry 4.0 in Ukraine» [13]. Вже 
створюються в Україні Центри Індустрії 4.0. А це є вже підставою для розбудови національної економіки на принципах нової реальності.

Висновок. На підставі аналізування макроекономічних показників та індикаторів державної спроможності виявлені деякі причини нової глобальної економічної кризи. Приводом ініціалізації та визнання цієї кризи став SARS-CoV-2, і світ опинився на порозі Next Normality. Ще 32011 року розпочала поширюватися Індустрія 4.0 як парадигма розвитку окремих проривних напрямів науки та формування новітніх освітніх програм на інженерних факультетах. Поєднання Next Normality та Industry 4.0 може сприяти Україні у 2020 році та у подальшому реальним зрушенням у розбудові інфраструктури української економіки. Для цього виявлені такі передумови: багатовікові освітні традиції українців; падіння (приведеної на одного працівника та до цін 2010 року) обсягів доданої вартості для промисловості та сфері послуг на рівень 1996 року; зростання з 2015 року цієї доданої вартості для національної економіки України; незначне, проте стале підвищення рівня політичної стабільності з 2014 до 2018 року (2019-2020 роки - дані не доступні); поступовий розвиток інноваційної інфраструктури України на засадах поєднання зусиль освіти та бізнесу в межах АППАУ та інших структур; використання решорингу як можливості створення нових підприємств на території України.

Науковою новизною $є$ запропонований методичний підхід до визначення наявності кризового стану у глобальній економіці на основі аналізування динаміки доданої вартості у промисловості та сфері послуг з обов'язковим приведенням цієї вартості до цін одного року та приведенні цієї вартості на одного працівника.

Подальших наукових досліджень потребує аналізування динаміки макроекономічних показників 3 метою визначення стану економік в умовах Next Normality та Industry 4.0.

\section{Лiтература:}

1. Next Normality: Let's prepare Next Normality \& Industry 4.0: онлайн формум. URL: https://appau.org.ua/event/ (Дата звернення 30.05.2020)

2. Індустрія 4.0 в Україні. URL: https://industry4-0-ukraine.com.ua/ (Дата звернення 15.06.2020)

3. Digital Magazine I4.0Today URL: http://i40today.com/ (Дата звернення 15.06.2020)

4. Hermann, M., Pentek, T., Otto, B. Design Principles for Industrie 4.0 Scenarios: A Literature Review. Working Paper. Technische Universität Dortmund. 2015. No. 01, URL:

https://www.researchgate.net/publication/307864150_Design_Principles_for_Industrie _40_Scenarios_A_Literature_Review (Дата звернення 19.07.2020).

5. Schwab K. The Fourth Industrial Revolution: what it means, how to respond. URL: https://www.foreignaffairs.com/articles/2015-12-12/fourth-industrial-revolution (Дата звернення 20.08.2020) 
6. Ангел С., Кравчук В. Яка промислова політика потрібна Україні для переходу до Індустрії 4.0? Дзеркало тижня. 2019. № 13

7. Калита П. Україна і четверта промислова революція: загрози та можливості. Дзеркало тижня. 2016. № 43-44.

8. Новак І., Покотиленко Р. Зайнятість в Індустрії 4.0: визначаємо національні пріоритети. Дзеркало тижня. 2019. № 3.

9. Ісаєвич Я. Львівська братська школа // Енциклопедія історії України : у 10 т. / редкол.: В. А. Смолій (голова) та ін. ; Інститут історії України НАН України. Київ : Наук. думка, 2009. Т. 6. 784 с.

10. Мелетій Смотрицький. Граматика слов'янська (1619). Підготовка факсимільного видання В. В. Німчука. Київ : Наукова думка, 1979. - (Пам'ятки української мови)

11. The World Bank Data and Research (2016), World Bank Statistics Database, retrieved from http://data.worldbank.org (Дата звернення 20.08.2020)

12. Kaufmann D. The Worldwide Governance Indicators: Methodology and Analytical Issues / D. Kaufmann, A. Kraay, M. Mastruzzi // World Bank Policy Research Working Paper, September, 2010. No. 5430. 31 p.

13. Юрчак О. та ін. Landscape Industry 4.0 in Ukraine: аналітичний огляд інноваторів та стану інновацій в Україні в сфері Індустрії 4.0. 76 с. URL: https://mautic.appau.org.ua/asset/83:landscape-industry-4-0-in-ukraine (Дата звернення 20.08.2020).

\section{References:}

1. Next Normality: Let's prepare Next Normality \& Industry 4.0: online forum. URL: https://appau.org.ua/event/ (Accessed 30 May 2020).

2. Industry 4.0 in Ukraine: the official website of the association, available at: https://industry4-0-ukraine.com.ua/ (Accessed 15 June 2020).

3. Digital Magazine I4.0Today, available at: http://i40today.com/ (Accessed 15 June 2020).

4. Hermann, M., Pentek, T., Otto, B. (2015), Design Principles for Industrie 4.0 Scenarios: A Literature Review, Working Paper, 2015, No. 01, available at: https://www.researchgate.net/publication/307864150_Design_Principles_for_Industrie _40_Scenarios_A_Literature_Review (Accessed 19 July 2020).

5. Schwab, K. (2016). The Fourth Industrial Revolution: what it means, how to respond. World Economic Forum, available at: https://www.foreignaffairs.com/articles/201512-12/fourth-industrial-revolution (Accessed 20 Aug 2020).

6. Anhel, Ye., Kravchuk, V. (2019). Yaka promyslova polityka potribna Ukraini dlia perekhodu do Industrii 4.0? Dzerkalo tyzhnia [The Mirror of the Week]. No. 13.

7. Kalyta, P. (2016). Ukraina i chetverta promyslova revoliutsiia: zahrozy ta mozhlyvosti, Dzerkalo tyzhnia [The Mirror of the Week]. No. 16, pp. 43-44.

8. Novak, I., Pokotylenko, R. (2019). Zajniatist' v Industrii 4.0: vyznachaiemo natsional'ni priorytety. Dzerkalo tyzhnia [The Mirror of the Week]. No. 3.

9. Isaievych, Ya. (2009), L'vivs'ka brats'ka shkola, Entsyklopediia istorii Ukrainy [Encyclopedia of the History of Ukraine], Naukova dumka, Kyiv, Ukraine.

10. Nimchuk V.V. (1979), Hramatyka slav'ians'ka [Slavic grammar]: preparation of a facsimile edition from Smotryts'kyj, Meletij (1619). Naukova dumka, Kyiv, Ukraine.

11. The World Bank Data and Research (2016), World Bank Statistics Database, available at http://data.worldbank.org (Accessed 20 Aug 2020).

12. Kaufmann, D. et al. (2010), The Worldwide Governance Indicators: Methodology and Analytical Issues, World Bank Policy Research Working Paper, No. 5430.31 p. 
13. Yurchak, O. et al. (2019). Landscape Industry 4.0 in Ukraine, APPAU, Kyiv, Ukraine, 76 p. available at: https://mautic.appau.org.ua/asset/83:landscape-industry-40-in-ukraine (Accessed 20 Aug 2020).

УДК 339.56

JEL classification: B11, E21, F15, O57

DOI:

Герасимчук В.Г.

доктор економічних наук, професор ORCID ID: 0000-0001-9357-8925

Національний технічний університет Украӥни

«Киїський політехнічний інститут імені Ігоря Сікорського»

\section{ВЕКТОРИ І МЕХАНІЗМИ КОНВЕРГЕНЦЇ̈ МОДЕЛЕЙ СОЦІАЛЬНО-ЕКОНОМІЧНОГО РОЗВИТКУ УКРАЇНИ ТА БОЛГАРІї}

\section{VECTORS AND MECHANISMS OF CONVERGENCE OF MODELS OF SOCIO- ECONOMIC DEVELOPMENT OF UKRAINE AND BULGARIA}

У статті розглянуто питання зовнішньоекономічної політики як однієї з найважливіших функиій держави. Аналізуються тенденції розвитку торговельноекономічних відносин між народами древньої Русі та Болгарією ще за часів IX-XIII ст., а також в період впровадження в Україні та Болгарії ринково-ліберальної моделі розвитку (з 1991р.). Досліджено відносини між народами двох країн 3 огляду на історичні зв'язки, етнічну, мовну та релігійну близькість, писемність (кирилиця), традиції та звичаї. Викладено критичний аналіз трансформачійних прочесів в сочіально-економічній сфері двох крайн у період з кіния 80-х років XX cm. до сьогодення (2020р.) Надана характеристика досягнутим результатам та існуючим проблемам в економічі Болгарії за роки ї̈ членства в СС. Звернено увагу на доцільність з боку України використовувати досвід Болгарії у процесі виконання Угоди про асочіацію між Украйною та ЄС. Виявлено вплив внутрішніх та зовнішніх факторів на формування та вдосконалення сочіально-економічних моделей розвитку двох краӥн. Досліджується динаміка, структура і ефрективність взаємної торгівлі найважливішими видами товарів та послуг з урахуванням переорієнтації векторів співпраці переважно з країн СНД на країни ЄС. Розроблено рекомендації щзодо активізачії товарообмінних операчій між двома державами. Розглянуто основні напрями конвергенції економічних моделей Украйни та Болгарї: дерегулювання економічної діяльності, створення спільних підприємств, диверсифікація єврорегіонального співробітництва, участь у технологічних програмах $Є С$, змічнення науково-технічних зв'язків, розвиток енергетичного комплексу, розщирення сфери надання туристичних послуг, впровадження нових форм вдосконалення фінансових механізмів та інструментів, перехід до ичифрової економіки. Запропоновано заходи щчодо посилення спільних дій, спрямованих на завоювання більш гідного місия і підвищення ролі України і Болгарії на європейському і світовому ринку товарів і послуг.

Ключові слова: європейська інтеграція, конвергенція, конкурентоспроможність, структура зовнішньої торгівлі, торговельно-економічні відносини, трансформаційні процеси, якість життя 